\title{
Application of phytoremediation in the management of oil spillage: A review
}

\author{
Angulu C. N. ${ }^{1 *}$, Atuluku S. A. ${ }^{1}$, Oladoja E. O $^{1}$., Balogun A. N. ${ }^{1}$, \\ Attah-Olottah, R. ${ }^{1}$ and Adeniyi, K. A. ${ }^{2}$ \\ 1Department of Microbiology, Federal University of Technology Minna, Nigeria. \\ 2Department of Animal Biology, Federal University of Technology Minna, Nigeria. \\ *Corresponding authors. Email: adeniyikamoru.a@gmail.com, calebndakoanguluangulu@gmail.com
}

Copyright @ 2018 Angulu et al. This article remains permanently open access under the terms of the Creative Commons Attribution License 4.0, which permits unrestricted use, distribution, and reproduction in any medium, provided the original work is properly cited.

Received 4th May, 2018; Accepted 16th July, 2018

\begin{abstract}
Crude oil production and distribution have increased the incidence of oil spills throughout the world. Oil spills often cause destructive effects on aquatic and land ecosystems. The oil spill clean-up and recovery techniques are challenging and usually involve complex mechanical, chemical, and biological methods. Usually, mechanical removal of free oil is utilized as an effective strategy for clean-up in aquatic and terrestrial environments; however, they are expensive and need specialist personnel and equipment. Phytoremediation is a green process that involves the use of plant in removing or degrading contaminants in the environment. Plants are able to remove pollutants through processes such as biodegradation, phytovolatilization, accumulation, and metabolic transformation. This review is focused on the impacts of oil spillage on the environment and the use of plants to extract, degrade, stabilize and volatilize spilled oil (management of oil spillage through phytoremediation) as well as the limitations of using phytoremediation in the management of oil spillage.
\end{abstract}

Key words: Biodegradation, contaminants, oil spillage, phytoremediation.

\section{INTRODUCTION}

The three-major segment of the petroleum industry includes the following, the exploration and production segment which include field works, refining and marketing segment that processes crude oil and gas into marketable products, and the supply infrastructure which is made up of transport structures used to transport crude oil and petroleum product from one locality to the other (Walls, 2010). In the process of all these operations, contamination of the environment is inevitable which could be through accidental or deliberate seepage and regulated discharging of waste to the surrounding (Ojuederie and Babalola, 2017). Oil spillage is one of the major problems faced by oil producing states. The management of this spillage has been a nightmare to oil producing environment (Spier et al., 2013). The spilled crude oil or refined petroleum products such as fuel or lube oils which contains toxic compounds like, hydrocarbons, nitrogen- oxygen compounds, sulphur compounds and heavy metals, which may cause acute and chronic effects on flora and fauna (Murakami et al., 2008). However, the toxicity and complexity of hydrocarbons in crude oil makes it remediation extremely difficult and known methods of managing this polluted site include the use of biological process, physical, thermal and chemical (Peng et al., 2009) of which could be done using a single or combination of methods based on the type and quantity of the pollutant and the weather condition. The application of each method has its merits and demerits, for quick clean up and prevention of oil spreading the physical and chemical methods which are considered as primary methods is used (Dave and Ghaly, 2011). The greatest limitations of these methods are the complexity of processes, the use of sophisticated equipment and subsequently lead to toxic effect or mechanical damage 
(Walls, 2010). The remediation of this pollution caused by oil spillage is very important, and this could be done using phytoremediation which is an integral part of bioremediation which solely deals with the use of plant to take out, contain or eliminate contaminant in their environment either by adsorption or transformation of this pollutant (Ndimele, 2010). According to Ndimele (2010), several species of plant has been shown to have the ability to grow in contaminated soils and actually extract the pollutant from the growth medium, such plants could solely do this or in conjunction with microorganisms. Thus, the objectives of this review are to give the general information about phytoremediation and use of plants for phytoremediation processes of oil spill from the environment.

\section{IMPACTS OF OIL SPILLAGE ON THE ENVIRONMENT}

Spillage of oil has a vast negative impact on both the water and soil of the ecosystem (Liang et al., 2009). The life of aquatic and other valuable resources in lakes, rivers and wetland are being threatened by oil spillage (Murakami et al., 2008). Other examples of undesirable impacts on oil spillage as reported by Jewett et al. (2002) and Murakami et al. (2008) include abnormal neurone development, genetic damage, physical deformities, as well as, changes in biological activities such as feeding, reproduction, and migration. Some animals are greatly affected with as little as $10 \mathrm{ml}$ of oil slick like the seabirds that suffers damage to their feather microstructure which leads to lethally reduced thermoregulation (O'Hara and Morandin, 2010).

Aquatic oil spill has been reported to also have an indirect effect on human health because some aquatic organisms have the ability to bioaccumulate high level of toxic hydrocarbon compounds fractions in their tissues and the final effect of the bioaccumulation of contaminants along with their subsequent transfer through the food chain, the pollutants can threaten human nutrient sources and health (Yang et al., 2009). León et al. (2013) and Xiu et al. (2014) reported the ability of the following aquatic organism; cockle (Cerastoderma glaucum), oyster (Ostrea edulis), noble pen shell (Pinna nobilis), blue mussel (Mytilus edulis), and turbot (Scophthalmus maximus) to accumulate polycyclic aromatic hydrocarbons (PAHs).

Terrestrial and aquatic plants are being exposed to both chemical and physical damage by oil spillage, reduction of photosynthesis and temperature regulation due to fouling of plant leaves and the coating of plant roots disrupts the root architecture plus water and nutrients uptake by the plant roots (Khan et al., 2013). Oil spillage lead to inhibition seed germination, decrease in plant biomass production and increased plant morality (Yang et al., 2009). The soil's physical, biological and chemical attributes are also negatively affected by oil spillage when the oil penetrates macro and micropores of the soil and thereby limiting water and air transport that are highly essential for organic matter conversion (Erdogan and Karaca, 2011). The different heavy metal gives different toxic effects on human health as shown in Table 1. Environmental pollution by heavy metals have increased as an influence of industrial development and it was shown that many heavy metals in high level was found in industrial areas (Adesuyi et al., 2015; Sumiahadi and Acar, 2018).

Heavy metals become a primary concern than other environmental pollutions because heavy metals canot be destroyed by degradation. The remediation process of contaminated soils, groundwater, and surface water by heavy metals needs some methods to remove the metals from contaminated areas (Sumiahadi and Acar, 2018). Several methods have been used for removing the pollutants from the contaminated environments. Soils that are contaminated with heavy metals can be treated by acid leaching, soil washing, physical or mechanical separation of the contaminant, electro-chemical treatment, electrokinetics, chemical treatment, thermal or pyrometalurgical separation and biochemical processes (Tangahu et al., 2011; Sumiahadi and Acar, 2018). Remediation techniques can be used for removing heavy metals from contaminated ground water are extraction and treatment by activated carbon adsorption, microbes use, air stripping (Sumiahadi and Acar, 2018), chemical, biological, biochemical and biosorptive treatment technologies (Sumiahadi and Acar, 2018). The use of some of these remediation techniques requires a high cost (Tangahu et al., 2011; Sumiahadi and Acar, 2018), a long time (Sumiahadi and Acar, 2018), logistical problems (Vangronsveld et al., 2009) and technical complexity (Ali et al., 2013). Therefore, alternative solution is needed for heavy metals removing from the environment. Bioremediation is an innovative and promising technology available for removal of heavy metals and recovery of the heavy metals in polluted water and lands (Dixit et al., 2015)

\section{PHYTOREMEDIATION OF OIL SPILLAGE}

Phytoremediation is one of bioremediation techniques that can be used as an alternative solution for heavy metal remediation process. The phytoremediation of metals is a cost-effective, efficient, environment- and eco-friendly 'green' technology based on the use of metalaccumulating plants to remove toxic metals, including radionuclides as well as organic pollutants from contaminated soils and water (Ali et al., 2013). Phytoremediation is defined as a sustainable and green process in which live plants are used for removing or degrading contaminants from the environment.

Phytoremediation was also defined by Tangahu et al. (2011) as the application of plants for extraction and sequestration followed by detoxification of the contaminants. The ability of plant to mediate numerous mechanisms in the removal of oil spill from polluted environment, by a remediation process which occurs as a 
Table 1. Toxic effects of some heavy metals on human health (Dixit et al., 2015).

\begin{tabular}{|c|c|c|}
\hline Heavy Metal & $\begin{array}{l}\text { EPA Regulatory Limit } \\
\text { (ppm) }\end{array}$ & Toxic Effects \\
\hline $\mathrm{Ag}$ & 0.10 & $\begin{array}{l}\text { Exposure may cause skin and other body tissues to turn gray or bluegray, breathing } \\
\text { problems, lung and throat irritation and stomach pain. }\end{array}$ \\
\hline As & 0.01 & $\begin{array}{l}\text { Affects essential cellular processes such asoxidative phosphorylation and ATP } \\
\text { synthesis }\end{array}$ \\
\hline $\mathrm{Ba}$ & 2.00 & $\begin{array}{l}\text { Cause cardiac arrhythmias, respiratory failure, gastrointestinal dysfunction, muscle } \\
\text { twitching and elevated blood pressure. }\end{array}$ \\
\hline $\mathrm{Cd}$ & 5.00 & $\begin{array}{l}\text { Carcinogenic, mutagenic, endocrine disruptor, lung damage and fragile bones, affects } \\
\text { calcium regulation in biological systems. }\end{array}$ \\
\hline $\mathrm{Cr}$ & 0.10 & Hair loss. \\
\hline $\mathrm{Cu}$ & 1.30 & $\begin{array}{l}\text { Brain and kidney damage, elevated levels result in liver cirrhosis and chronic anemia, } \\
\text { stomach and intestine irritation. }\end{array}$ \\
\hline $\mathrm{Hg}$ & 2.00 & $\begin{array}{l}\text { Autoimmune diseases, depression, drowsiness, fatigue, hair loss, insomnia, loss of } \\
\text { memory, restlessness, disturbance of vision, tremors, temper outbursts, brain } \\
\text { damage, lung and kidney failure }\end{array}$ \\
\hline $\mathrm{Ni}$ & 0.20 & $\begin{array}{l}\text { Allergic skin diseases such as itching, cancer of the lungs, nose, sinuses, throat } \\
\text { through continuous inhalation, immunotoxic, neurotoxic, genotoxic, affects fertility, } \\
\text { hair loss. }\end{array}$ \\
\hline $\mathrm{Pb}$ & 15.00 & $\begin{array}{l}\text { Excess exposure in children causes impaired development, reduced intelligence, } \\
\text { short-term memory loss, disabilities in learning and coordination problems, risk of } \\
\text { cardiovascular disease. }\end{array}$ \\
\hline $\mathrm{Se}$ & 50.00 & $\begin{array}{l}\text { Dietary exposure of around } 300 \mu \mathrm{g} \text { day- } 1 \text { affects endocrine function, impairment of } \\
\text { natural killer cells activity, hepatotoxicity and gastrointestinal disturbaces. }\end{array}$ \\
\hline $\mathrm{Zn}$ & 0.50 & Dizziness, fatigue etc. \\
\hline
\end{tabular}

EPA: United State Environmental Protection Agency.

result complex interaction of roots, roots exudate, rhizhosphere, and microbes which is termed as rhizoremediation (Khan et al., 2013). The interactions between the root system of higher plants are not only with soil environment but also with a different community of metabolically effective microorganisms. The living plants create a special habitat on and around the roots where the microbial population is considerably more than that of root free soil environment ( $\mathrm{Lu}$ et al., 2010). Around $40 \%$ of plants photosynthate roots exudates such as sugars, organic acids, and aromatic compounds, which are rich in carbon and energy for microbial growth, are produced into the soil (Khan et al., 2013). Chemotactic response of microbes for motility towards the roots and formation of root colonization, which consequently stimulate growth and activity of microorganisms for the degradation of organic pollutants are initiated by these exudates (Gerhardt et al., 2009). The distinct chemical compositions and rates of exudation have different effects on microorganisms in different species; hence, the degradation activity is brought about by the individual composition of plant exudates (Bais et al., 2006). Plant roots are also able to produce oxygen for microorganisms in the rhizosphere and through the penetration of oxygen into the soil and improvement of the soil structure the oxidative degradation of hydrocarbons is increased. The end products of degradation include alcohol, acids, carbon dioxide, and water, which are less toxic and less persistent than the primary compounds (Gerhardt et al., 2009).

\section{PHYTOREMEDIATION AND ITS MECHANISMS}

The term "phytoremediation" is relatively new, started from 1991. The term "phytoremediation" consists of the Greek prefix phyto which is means 'plant' and the Latin root remedium which is means 'to correct or remove evil'. Basic information for phytoremediation comes from a variety of research areas including constructed wetlands, oil spills, and agricultural plant accumulation of heavy metals. The term has been used widely since its inception, with a variety of specific meanings (EPA, 2000) (Figure 1).

Many definitions of phytoremediation have been given by researchers. According to those definitions, Tangahu et al. (2011) made a general definition of phytoremediation as an emerging technology using selected plants to clean up the contaminated environment from hazardous contaminant to improve the environment quality. EPA (2000) noted that phytoremediation has been receiving attention lately as an innovative, cost-effective alternative to the more established treatment methods used at hazardous waste sites. Ali (2013) called phytoremediation as 'green technology' because of its advantages as a costeffective, efficient, environment- and eco-friendly technology. 


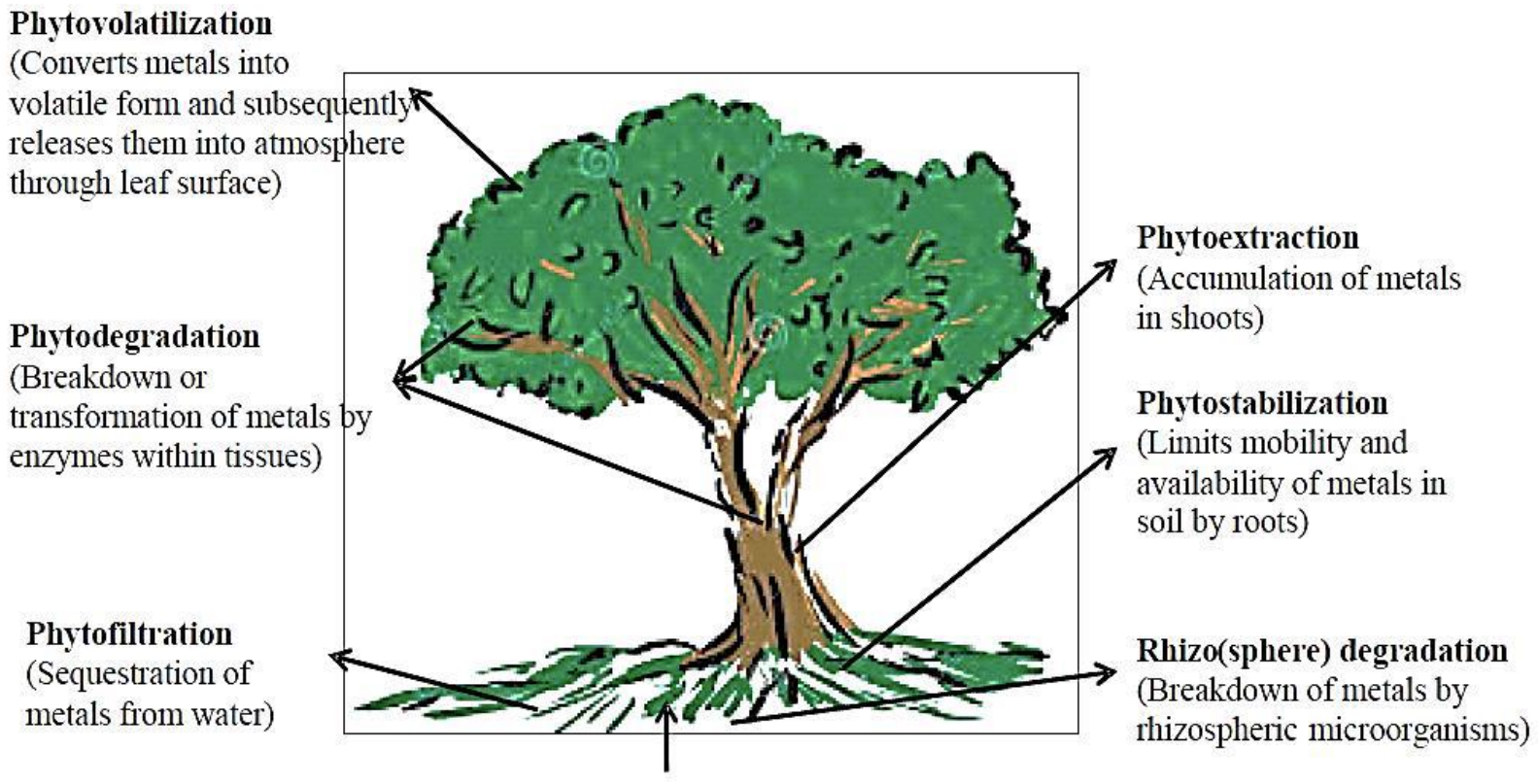

Uptake

Figure 1. Various mechanisms involved in the phytoremediation of heavy metals (Dixit et al., 2015).

\section{Phytoremediation of oil spillage in soils}

Plants initially possessed good tolerance against crude oilcontaminated soil. For instance, the four o'clock flower (Mirabilis jalapa L.) was successfully demonstrated as a phytoremediator due to having the ability to tolerate crude oil contamination (Peng et al., 2009). The removal efficiency of total petroleum hydrocarbons (TPHs) was doubled by $M$. jalapa over a 127-day period (Peng et al., 2009).

Forest tree species such as teak (Tectona grandis) and gmelina (Gmelina arborea) have shown acceptable abilities to thrive well in a contaminated habitat having crude oil up to $10 \% \mathrm{w} / \mathrm{w}$ of soil. However, biomass and height of the test plants were significantly affected at higher levels of oil treatments (Agbogidi et al., 2007). Branquilho (Sebastiania commersoniana), a Brazilian native tree, have been also proved to be tolerant to soil petroleum contamination. This tree decreased petroleum hydrocarbons up to $94 \%$ in contaminated soil (Ramos et al., 2009). Seed germination and early growth of seven plant species including corn (Zea mays), millet (Panicum miliaceum), sorghum (Sorghum bicolor), lettuce (Lactuca sativa), okra (Abelmoschus esculents), watermelon (Citrullus lanatus), and soybean (Glycine max) were evaluated in experimental systems contaminated with oil field produced water. Results indicated a high tolerance of sorghum, okra, millet, and corn to oil phytotoxicity compared to others (Pardue et al., 2015). Two crop species, corn (Z. mays) and soybean (G. max), have also demonstrated tolerance to crude oil-contaminated soils (Issoufi et al., 2006).
The plant potential for petroleum hydrocarbon bioaccumulation is another characteristic that makes plants suitable for phytoremediation. A high bioaccumulation of BTEX (benzene, toluene, ethylbenzene, and xylenes) in shoots of canna lily (Canna indica L.) was reported by Boonsaner et al. (2011). Canna removed $80 \%$ of BTEX in the root zone soil in 21 days. The tropical ornamental shrub, Siam weed (Chromolaena odorata L.), showed high capability of phytoaccumulation in soils contaminated with crude oil and heavy metals. These species removed up to $80 \%$ crude oil from soil polluted with oil and heavy metals (Atagana, 2011).

The physical and morphological characteristics of roots in some vegetation make them able to attract more microorganisms around their roots and stimulate hydrocarbon degradation (Ansari et al., 2014). The roots of mulberry (Morus spp.), apple (Malus domestica), and osage orange (Maclura pomifera) trees have been reported to release flavonoids and phenolic compounds which stimulate PAH-degrading bacteria (Atagana, 2011). Garden balsam (Impatiens balsamina L.) was reported as a potential ornamental plant for effective removal of oil from contaminated soils. During the 4 month culture period, the population of living microorganisms around the plant root showed a significant increase, which played the main role in oil degradation (Cai et al., 2010). In a laboratory phytoremediation study, degradation, volatilization, and mass reduction of benzene in effluents was enhanced by hybrid poplar cuttings (Populus deltoids Populus nigra) planted in flow-through reactors supplied with benzene (Ojuederie and Babalola, 2017). Grasses such as annual ryegrass (Lolium multiflorum), bread grass 
(Brachiaria brizantha), nut grass (Cyperus rotundus), and mullumbimby couch (Cyperus brevifolius Rottb.) are considered to be ideal for phytoremediation due to ramified, extensive, and fibrous root systems, which offer a maximum root surface area (White et al., 2006; Basumatary et al., 2012a; Basumatary et al., 2012b). The perennial grasses, tall fescue (Festuca arundinacea Schreb.), and perennial ryegrass (Lolium perenne L.) have also been selected for oil phytoremediation having extensive root systems and robust growth after establishment (Cook and Hesterberg, 2013).

Unlike surface root system, plant species with a tap root system are able to reach deeper soil layers or the water table and impact on deeper located contaminants (Kang et al., 2016). Deep-rooted trees such as poplars (Populus spp.) and willows (Salix spp.) have been successfully used for water uptake from groundwater containing total petroleum hydrocarbons (Ferro et al., 2013).

The most important factor affecting the rate of metal removal in phytoremediation is plant selection to be used as accumulator. Sumiahadi and Acar (2018) has described some considerations for the selection of remediating plants:

- The plant biomass, the metal removal rate depends on the plant biomass harvested and metal concentration in harvested biomass.

- Ecosystem protection, native species are preferred to exotic plants, which can be invasive and endanger the harmony of the ecosystem. To avoid propagation of weedy species, crops are in general preferred, although some crops may be too palatable and pose a risk to grazing animals.

- Physical characteristics of soil contamination, for the remediation of surface-contaminated soils, shallow rooted species would be appropriate to use, whereas deep-rooted plants would be the choice for more profound contamination.

\section{Phytoremediation of crude oil spills in aquatic ecosystem}

In aquatic ecosystems such as lakes, rivers, and wetlands, there are different types of plants termed macrophytes thriving in or near water that are emergent, submergent, or floating (Bhatia and Goyal, 2014). They can be possibly used as oil hydrocarbon phytoremediators. One of the characteristics that make them suitable for phytoremediation is their ability to grow fast. They are invasive and rapidly become abundant. Thus, they can be replaced with new growth soon after the damage caused by oil pollution (Bhatia and Goyal, 2014). The fibrous roots of some aquatic plants can provide larger surface and denser rhizospheres for microbial colonization (White et al., 2006). Ndimele (2010) reported that water hyacinths' (Eichhornia crassipes) fibrous root systems are able to significantly remediate the floating petroleum hydrocarbons on surface waters. Biscuit grasses (Paspalum vaginatum Sw.) were also reported to be potential candidates for petroleum hydrocarbons phytoremediation. Their root system facilitated survival and growth in diesel-contaminated sands (up to $30 \mathrm{~g}^{\mathrm{kg}} \mathrm{kg}^{-1}$ ) (Sanusi et al., 2012). Reeds, dominant coastal wetland plants, can also provide strong vitality and great root surface area which is beneficial for restoring the petroleum-contaminated wetlands (Wang et al., 2011). Four fresh-marsh plant species, alligator weed (Alternanthera philoxeroides), maidencane (Panicum hemitomon), common reed (Phragmites australis), and duck potato (Sagittaria lancifolia) effectively phytoremediated South Louisiana Sweet Crude oil in contaminated mesocosms (Ojuederie and Babalola, 2017).

In aquatic ecosystems, due to hypoxic and anoxic conditions of sediments or soils, anaerobic degradation of crude oil happens which is a very slow and incomplete process. Some macrophytes transport atmospheric oxygen from the shoots to the roots and increase the aerobic respiration of rhizosphere microbes (Kang et al., 2016; Moreira et al., 2011). This is a natural mechanism of wetland plants, or submerged aquatic macrophytes, which makes them able to oxygenate their root zone to protect themselves against phytotoxins (e.g., $\mathrm{Fe} 2+, \mathrm{Mn} 2+$, and H2S) (Kang et al., 2016). Huesemann et al. (2009) have shown that eelgrass (Zostera marina), a marine macrophyte, can significantly remove polynuclear aromatic hydrocarbons and polychlorinated biphenyls in submerged marine sediments. The enhanced rhizosphere biodegradation through root exudates, oxygen, and plant enzymes was the dominant removal process. Red mangrove (Rizophora mangle L.) has also been reported to increase the bacteria density in the rhizosphere ten times more than bulk sediments, possibly through the entry of oxygen into the sediments (Moreira et al., 2011). Similarly, the aquatic weed cattails (Typhaq spp.) have been demonstrated to release higher rates of oxygen into their rhizospheres compared to the coastal salt marsh black rushes (Juncus roemerianus) with the difference in oxygen release intensity between plant species found to be related to the redox state of the rhizosphere (Kang et al., 2016). In a horizontal-vertical flow constructed wetland, cattail and bulrush (Scirpus lacustris) removed $99.9 \%$ of phenanthrene (Lin and Mendelssohn, 2009), while black rush, a dominant coastal salt marsh plant, effectively reduced total petroleum hydrocarbons (TPH) up to $15 \%$ in contaminated sediments (Lin and Mendelssohn, 2009).

In floating species, where the root system does not establish into a solid matrix, the ability of plants for bioaccumulation and biosorption of pollutants from the liquid medium make them able to be considered as phytoremediators (Ojuederie and Babalola, 2017; Rahman and Hasegawa, 2011). There are some phytoremediation studies on floating plants such as water lettuce (Pistia 
stratiotes Linn.) and duckweed (Spirodela polyrrhiza Trev.) for removing crude oils of oil-polluted water bodies. However, their performance was not promising (Rahman and Hasegawa, 2011). In general, there are few studies to identify the ability of aquatic species for crude oil phytoremediation. Since most oil spills occur in aquatic environments, the need to test the efficiency of aquatic macrophytes seems to be necessary.

\section{CONCLUSION}

Phytoremediation is a remediation technology to clean up the contaminants from environment by using green plants. Phytoremediation can be an alternative solution as a green technology to treat oil spill contaminated areas. According to previous studies, several plants have a high potential as heavy metals bioaccumulator and can be used for phytoremediation process of oil spill. The impact of oil spills can either be acute or chronic on the surrounding ecosystems. Thermal, mechanical, and chemical methods applied for the remediation of these contaminants are expensive, disruptive to the environment, and energy consuming. Phytoremediation, as an area of bioremediation, has been developed to be an eco-friendly and cost-effective clean up technique. It uses the ability of plants to extract, degrade, stabilize, and volatilize the contaminants located in land and aquatic environments. Therefore, phytoremediation is generally applied as an in situ and non-destructive technique, which not only remediates organic pollutants effectively but also improves the soil condition and prevents soil erosion. However, its application may be limited due to the nature of plants. High initial concentrations of contaminants can cause oxidative stress and toxic and inhibitor effects on plant roots. Hence, phytoremediation can be applied either in low polluted areas or as a final treatment of highly polluted areas. Besides, phytoremediation may not be effective in low temperature environment when the plant growth is slow or stopped. Application of phytoremediation may require greater land areas compared to other remediation methods. Phytoremediation of petroleum hydrocarbon has potential to remediate polluted areas. Nevertheless, phytoremediator species, phytoremediation sites, efficiencies, and probable risks to achieve efficient remediation technique are factors that are required for further investigations.

\section{CONFLICT OF INTEREST}

The authors declare that they have no conflict of interest.

\section{REFERENCES}

Adesuyi, A. A., Hjoku, K. L., \& Akinola, M. O. (2015). Assassment of heavy metals pollution in soil and vegetation around selected industries in Lagos State, Nigeria Journal Geoscience
Environmental Protection, 3 11-19.

Ali, H., Khan, E. \& Sajad, M. A. (2013). Phytoremediation of heavy metals - concepts and applications

Chemosphere, 91 869-81.

Ansari, A. A., Gill, S. S., Gill, R., Lanza, G. R., \& Newman, L. (Eds.). (2014). Phytoremediation: management of environmental contaminants (vol. 1). Springer.

Atagana, H. I. (2011). Bioremediation of co-contamination of crudeoil and heavy metals in soil by phytoremediation using Chromolaena odorata (L) King and HE Robinson. Water, Air, and Soil Pollution, 215(1-4), 261-271.

Bais, H. P., Weir, T. L., Perry, L. G., Gilroy, S., \& Vivanco, J. M. (2006). The role of root exudates in rhizosphere interactions with plants and other organisms. Annual Review of Plant Biology, 57, 233-266.

Basumatary, B., Saikia, R., \& Bordoloi, S. (2012a). Phytoremediation of crude oil contaminated soil using nut grass, Cyperus rotundus. Journal of environmental biology, 33(5), 891.

Basumatary, B., Bordoloi, S., \& Sarma, H. P. (2012b). Crude oil contaminated soil phytoremediation by using Cyperus brevifolius (Rottb.) Hassk. Water, Air, and Soil Pollution, 223(6), 3373-3383.

Bhatia, M., \& Goyal, D. (2014). Analyzing remediation potential of wastewater through wetland plants: a review. Environmental Progress and Sustainable Energy, 33(1), 9-27.

Boonsaner, M., Borrirukwisitsak, S., \& Boonsaner, A. (2011). Phytoremediation of BTEX contaminated soil by Canna generalis. Ecotoxicology and Environmental Safety, 74(6), 1700-1707.

Cai, Z., Zhou, Q., Peng, S., \& Li, K. (2010). Promotion biodegradation and microbiological effects of petroleum hydrocarbons by Impatiens balsamina L. with strong endurance. Journal of Hazardous Materials, 183(1), 731-737.

Cook, R. L., \& Hesterberg, D. (2013). Comparison of trees and grasses for rhizoremediation of petroleum hydrocarbons. International journal of phytoremediation, 15(9), 844-860.

Dixit, R., Wasiulah, G., Malaviya, D., Pandiyan, K., Singh, U. B., Sahu, A., Shukla, R., Singh, B. P., Rai, J. P., Sharma, P. K., Lade, H., \& Paul, D. (2015). Bioremediation of heavy metals from soil and aquatic environment: An overview of principles and criteria of fundamental processes Sustainability 7, 2189212

Dave, D., \& Ghaly, A. E. (2011). Remediation technologies for marine oil spills: a critical review and comparative analysis. American Journal of Environmental Sciences, 7(5), 423.

Erdogan, E. E., \& Karaca, A. (2011). Bioremediation of crude oil polluted soils. Asian Journal of Biotechnology, 3,206-213.

EPA (U.S. Environmental Protection Agency) (2000). Introduction to Phytoremediation (Ohio: State Environmental Protection Agency). p. 104.

Ferro, A. M., Adham, T., Berra, B., \& Tsao, D. (2013). Performance of deep-rooted phreatophytic trees at a site containing total petroleum hydrocarbons. International Journal of Phytoremediation, 15(3), 232-244.

Gerhardt, K. E., Huang, X. D., Glick, B. R., \& Greenberg, B. M. (2009). Phytoremediation and rhizoremediation of organic soil contaminants: potential and challenges. Plant Science, 176(1), 20-30.

Huesemann, M. H., Hausmann, T. S., Fortman, T. J., Thom, R. M., \& Cullinan, V. (2009). In situ phytoremediation of PAH-and PCB-contaminated marine sediments with eelgrass (Zostera marina). Ecological Engineering, 35(10), 1395-1404.

Issoufi, I., Rhykerd, R. L., \& Smiciklas, K. D. (2006). Seedling 
growth of agronomic crops in crude oil contaminated soil. Journal of Agronomy and Crop Science, 192(4), 310-317.

Jewett, S. C., Dean, T. A., Woodin, B. R., Hoberg, M. K., \& Stegeman, J. J. (2002). Exposure to hydrocarbons 10 years after the Exxon Valdez oil spill: evidence from cytochrome P4501A expression and biliary FACs in nearshore demersal fishes. Marine Environmental Research, 54(1), 21-48.

Kang, C. H., Kwon, Y. J., \& So, J. S. (2016). Bioremediation of heavy metals by using bacterial mixtures. Ecological Engineering, 89, 64-69.

Khan, S., Afzal, M., Igbal, S., \& Khan, Q. M. (2013). Plantbacteria partnerships for the remediation of hydrocarbon contaminated soils. Chemosphere, 90(4), 1317-1332.

León, V. M., Moreno-González, R., González, E., Martínez, F., García, V., \& Campillo, J. A. (2013). Interspecific comparison of polycyclic aromatic hydrocarbons and persistent organochlorines bioaccumulation in bivalves from a Mediterranean coastal lagoon. Science of the Total Environment, 463,975-987.

Liang, Y., Zhang, X., Dai, D., \& Li, G. (2009). Porous biocarrier enhanced biodegradation of crude oil contaminated soil. International Biodeterioration and Biodegradation, 63(1), 8087.

Lin, Q., \& Mendelssohn, I.A. (2009). Potential of restoration and phytoremediation with Juncus roemerianus for diesel contaminated coastal wetlands. Ecological Engineering, 35(1), 85-91.

Lu, M., Zhang, Z., Sun, S., Wei, X., Wang, Q., \& Su, Y. (2010). The use of goosegrass (Eleusine indica) to remediate soil contaminated with petroleum. Water, Air, and Soil Pollution, 209(1-4), 181-189.

Agbogidi, M. O., Dolor, D. E., \& Okechukwu, M. E. (2007). Evaluation of Tectona grandis (Linn.) and Gmelina arborea (Roxb.) for phytoremediation in crude oil contaminated soils. Agriculture Conspectus Scientificus (ACS), 72(2), 149-152.

Moreira, I. T., Oliveira, O. M., Triguis, J. A., dos Santos, A. M., Queiroz, A. F., Martins, C. M., ... \& Jesus, R. S. (2011). Phytoremediation using Rizophora mangle L. in mangrove sediments contaminated by persistent total petroleum hydrocarbons (TPH's). Microchemical Journal, 99(2), 376-382.

Murakami, Y., Kitamura, S. I., Nakayama, K., Matsuoka, S., \& Sakaguchi, H. (2008). Effects of heavy oil in the developing spotted halibut, Verasper variegatus. Marine Pollution Bulletin, 57(6), 524-528.

Ndimele, P. E. (2010). A review on the phytoremediation of petroleum hydrocarbon. Pakistan Journal of Biological Sciences, 13(15), 715.

Ndimele, P. E., Kumolu-Johnson, C. A., \& Anetekhai, M. A. (2011). The invasive aqatic macrophyte, water hyacinth \{Eichhornia crassipes (Mart.) Solm-Laubach: Pontedericeae\}: problems and prospects. Research Journal Environmental Sciences, 5(6), 509-520.

Ojuederie, O. B., \& Babalola, O. O. (2017). Microbial and PlantAssisted Bioremediation of Heavy Metal Polluted Environments: A Review. International journal of environmental research and public health, 14(12), 1504.

O'Hara, P. D., \& Morandin, L. A. (2010). Effects of sheens associated with offshore oil and gas development on the feather microstructure of pelagic seabirds. Marine Pollution Bulletin, 60(5), 672-678.
Pardue, M. J., Castle, J. W., Rodgers, J. H., Jr., \& Huddleston, G. M., III. (2015). Effects of simulated oilfield produced water on early seedling growth after treatment in a pilot-scale constructed wetland system. International Journal of Phytoremediation, 17(4), 330-340.

Peng, S., Zhou, Q., Cai, Z., \& Zhang, Z. (2009). Phytoremediation of petroleum contaminated soils by Mirabilis jalapa L. in a greenhouse plot experiment. Journal of Hazardous Materials, 168(2), 1490-1496.

Ramos, D. T., Maranho, L. T., Godoi, A. F. L., da Silva Carvalho Filho, M. A., Lacerda, L. G., \& de Vasconcelos, E. C. (2009). Petroleum hydrocarbons rhizodegradation by Sebastiania commersoniana (BAILL.) L. B. SM. and Downs. Water, Air, and Soil Pollution, 9(3-4), 293-302.

Rahman, M. A., \& Hasegawa, H. (2011). Aquatic arsenic: phytoremediation using floating macrophytes. Chemosphere, 83(5), 633-646.

Sumiahadi, A., \& Acar, R. (2018, March). A review of phytoremediation technology: heavy metals uptake by plants. In IOP Conference Series: Earth and Environmental Science, 142(1), 012023).

Sanusi, S. N. A., Abdullah, S. R. S., \& Idris, M. (2012). Preliminary test of phytoremediation of hydrocarbon contaminated soil using Paspalum vaginatum Sw. Australian Journal of Basic and Applied Sciences, 6(1), 39-42.

Spier, C., Stringfellow, W. T., Hazen, T. C., \& Conrad, M. (2013). Distribution of hydrocarbons released during the 2010 MC252 oil spill in deep offshore waters. Environmental Pollution, 173, 224-230.

Tangahu, V.B., Abdullah, S. R. S., Basri, H., Idris, M. Anuar, N. \& Mukhlisin, M. (2011). A review of heavy metal (As, $\mathrm{Pb}$ and $\mathrm{Hg}$ ) uptake by plants through phytoremediation. International Journal of Chemical Engineering, 21, 1- 31.

Vangronsveld, J., Herzig, R., Weyens, N., Boulet, J., Adriaensen, K., Ruttens, A., Thewys, T., Vassilev, A., Meers, E., Nehnevajova, E., \& van der Lelie, D. (2009). Phytoremediation of contaminated soils and groundwater: lessons from the field. Environmental Science and Pollution Research, 16(7), 765-794.

Walls, W. D. (2010). Petroleum refining industry in China. Energy Policy, 38(5), 2110-2115.

Wang, J., Liu, X., Zhang, X., Liang, X., \& Zhang, W. (2011). Growth response and phytoremediation ability of Reed for diesel contaminant. Procedia Environmental Sciences, 8, 6874.

White, P. M., Jr., Wolf, D. C., Thoma, G. J., \& Reynolds, C. M (2006). Phytoremediation of alkylated polycyclic aromatic hydrocarbons in a crude oil-contaminated soil. Water, Air, and Soil Pollution, 169(1-4), 207-220.

Xiu, M., Pan, L., \& Jin, Q. (2014). Bioaccumulation and oxidative Damage injuvenile scallop Chlamys farreri exposed to benzo [a] pyrene, benzo [b] fluoranthene and chrysene. Ecotoxicology and Environmental Safety, 107,103-110. 